\title{
Entry Mode of Offshore School Enterprises from English Speaking Countries
}

\author{
Parkes, Michael ${ }^{1} \&$ Han, $\mathrm{I}^{1}$ \\ ${ }^{1}$ School of Business, Feng Chia University, Taichung, Taiwan \\ Correspondence: Han, I, Department of International Trade, School of Business, Feng Chia University, Taichung, \\ Taiwan. Tel: 886-4-2451-7250 ext. 4269. E-mail: ihan@ fcu.edu.tw
}

Received: April 13, 2015

Accepted: May 5, 2015

Online Published: May 25, 2015

doi:10.5539/ibr.v8n6p174

URL: http://dx.doi.org/10.5539/ibr.v8n6p174

\begin{abstract}
Offshore schools are for-profit educational services designed to grant home government recognised high school diplomas to students in an overseas country. This paper takes the theoretical perspectives of institutions and transaction cost economics to investigate how offshore school multinational enterprises choose the entry mode in foreign direct investment. We create a dataset for offshore schools from developed English-speaking countries to provide supporting evidence. We find that resulting from stringent regulations on the education system by home country authorities, offshore school enterprises tend to choose the high control mode in the host country when the specificity of investments is high, particularly in feeder schools as the guaranteed parent university admission with an offshore school high school diploma. Our study provides theoretical implications on entry mode choices upon home country institutions, as well as temporal specificity of the feeder school investment.
\end{abstract}

Keywords: entry mode, transaction cost, institutions, offshore school enterprise

\section{Introduction}

The offshore schools industry has brought together the fields of international business and education for mutual goals. These two fields have not formed partnerships and institutional relationships before, and the result is a new and expanding industry worthy of examination. However, there has been scant academic and methodological analysis of offshore schools and the various players involved. This industry is a prime example of the real life practise of the theories of foreign direct investment (FDI), transaction cost economics (TCE), and Institutions. This paper aims at examining this new hybrid of business and education and try to spark a more serious and rigorous academic analysis of this industry.

Global society has adjusted to the neoliberal paradigm that there are no common goods, only private commodities to invest in, consume and exploit (Singh, 2010). Education has seen a shift away from the public sector towards the private sector. Governments have reduced funding to public, government-run schools (Schuetze, Kuehn, Davidson-Harden, Schugurensky, \& Weber, 2011). Nevertheless, people recognise the importance of education in their lives. Education empowers people with new sets of knowledge. It helps impart important skills useful for employment and participation as full citizens in society.

In this context, business and education have formed partnerships for the delivering of educational outcomes in the private sector. Overseas education has transformed into a service business (BCCIE, 2011). For-profit schools, with regulatory oversight for the delivery of government recognised diplomas, are popular in such countries as China, Korea, and Colombia. Access to education higher in quality than delivered by local authorities has shifted consumer value conceptions of education. Its flexibility of location and providing access to previously geographically barred sections of populations has witnessed explosive growth in the past decade.

Offshore schools have employed a variety of FDI entry modes to meet a demand for obtaining out-of-country secondary school diplomas. For the government authorities issuing their diplomas overseas, this has shifted the concept of delivering education from being a common good to being a private service. For the businesses that team with government authorities to deliver said education, this has resulted in utilising the most efficient means of decreasing transaction costs while engaging in these cross-sector partnerships. The problems encountered in this emerging industry have been difficulties around differences in culture, economics, political regimes, geography, linguistic backgrounds and regulatory frameworks (Das, 2004). How to integrate disconnected 
regulatory regimes of education with multinational enterprises for the single purpose of delivering a formerly domestic program across international and even continental lines has been an ongoing dilemma.

International business and education fields have not intersected before. Inquiry is demanded as the growing industry of offshore schools gains greater accumulation of data, historical records, economic presence, and information on business-education-regulatory interaction. How governments and their education authorities adapt to this new paradigm merits observation. How private enterprise understands and comprehends the nature of regulations affecting education should be explored. As well, how such educational international businesses should select the entry mode for the fit of superior performance. Our research and analysis of this subject is conducted to help generate interest in research between the fields of education and international business.

This paper provides research on offshore schools and their operations in countries outside their home education authorities' jurisdiction. This study aims at comparing various theoretical backgrounds against real life information being produced regarding the aforementioned subject matter. In addition, the quantitative study of a collection of schools from English-speaking countries made for the purpose of identifying patterns. This paper is organized as follows. After a brief introduction of research objectives, motivations and questions of this study, we then provide an explanation of offshore schools. After that, we apply international business entry mode theories to explain offshore school entry mode choices and formulate the hypotheses. It also discusses major theories and empirical studies from the past. The methodology section provides the research method and analyses results. Based on our empirical results, we discuss significant implications and interpretations, as well as explanations for nonsignificant findings. Finally, our contributions from theoretical and empirical implications will be concluded and outlines limitations, well as future research will be given before the conclusions.

\section{The Offshore School}

Offshore schools are for-profit, private sector educational services established for granting home government recognised high school diplomas to students in an overseas country. The schools are most often main or secondary components of investment companies (Schuetze, 2008). These parent companies are under the regulatory oversight of education authorities, each authority being a Ministry or Department of Education originating from a home country, or "home education authorities".

The international business of offshore schools are regarded as subsidiaries producing students with high school diplomas. The universities that receive the students are likened to firm headquarters seeking input of productive goods towards their goals and simultaneously transmitting information back to the subsidiaries on further need for resources. Such headquarters-subsidiary in this context transfers the 'unfinished product' being the high school graduate going on to university for further education. Human resource management is unique in this regard as it pertains not just to the staff and faculty but also the subject of the enterprise; the students.

Students attending this school are locals seeking to obtain a foreign high school diploma (Jiang \& Feng, 2006). The offshore school grants high school diplomas recognised by the parent company's home education authority at the end of the term of study. Offshore schools operate mostly at the middle and secondary school level. Very few of these schools offer primary or elementary level education (Cosco, 2011). Some act as "feeders" to directly transfer their diploma-granted students to the home country university locus for college studies, whereas the rest of non-feeder offshore schools students are highly recognised by universities regulated by the home education authorities.

Offshore schools employ teachers given certification to instruct on the curricula set out by the home education authority. They are contracted to transport from the home country to the country where the school campus is located. These teachers are never locals of the host country, but foreign nationals from the home country with licensed credentials. Only in circumstances where the local education authority demands some adherence to the local curricula will local teachers be hired to instruct on certain subjects (State Council, 2003). In the future, offshore school alumni may obtain home country teaching credentials at home country universities to teach back at their alma mater, but this has yet to occur (Steffenhagen, 2013).

According to Dunning $(1988,1998)$, four FDI motivations determine the overseas location of offshore schools. The first is that they are resource seeking in that they gravitate towards jurisdictions that allow for the establishment of such organisations. The second is that they are market seeking where demand for such educational opportunities is high and where customers are willing to pay high tuition (Scheutze, 2008) for the privilege to study at these schools. The third is they are efficiency seeking in that they seek partners in the host country willing and able to invest in such enterprises and can reduce transaction costs normally associated with multinational operations. The fourth is that they seek strategic assets through exploiting opportunities to establish and gain market share to ensure clientele and profit maximisation. The offshore school's headquarters operating 
standard here is that home country authorities matter, whereas the host country is selected as a location motivation (Dunning, 1998).

The FDI entry modes in offshore school cover all alternatives. In addition to the wholly-owned mode, the parent company may partner with a local educational institute to deliver the home country curriculum for handling transaction costs to partner with a local firm (Williamson, 1981). The local parent company is in charge of the business aspect of the school, and has legal and political power due to their local nature (Kheun, 2002). As the indigenous face of the offshore school, it reduces exogenous costs for the home parent company regarding operations, regulations and customs (Zhao \& Decker, 2003).

English-speaking countries dominating this global business relates to the obvious nature of the English language being the international 'lingua franca'. It is logically more desirable to obtain a diploma from an English-speaking country than, say, from a French or Spanish or Chinese or Hindi-speaking country. As such, the institutes of English-speaking countries, namely the educational, scientific, industrial and professional standards, are considered world class (BCMOE, 2013). For this reason, customer and student demand gravitates towards diplomas from English-speaking jurisdictions.

In China, for example, offshore schools are designated as Chinese-foreign cooperation institutions and must meet a number of requirements (State Council, 2003; Wen, 2005). These include a prescribed organizational structure, be authorized by provincial and municipal authorities, and may not compete with primary and secondary public schooling. (Tan, 2009; Xiang \& Shen, 2009). As of 2008, the top ten countries operating offshore schools in China were the United States (154), Australia (146), Canada (74), Japan (58), Hong Kong (56), Singapore (46), UK (40), Taiwan (31), France (24), Germany (14) and South Korea (12) (Schuetze, 2008). Of these, schools from English-speaking countries number 414 out of 655 , or $63.2 \%$ of the total. Offshore schools can provide a more practical means of providing academic experience to local students without having to travel far and pay high costs, leave their country of origin and be out of a familiar environment at a young age (Scheutze et al., 2011; Xiang \& Shen, 2009; Waters, 2006). Consequently, there is a growing market for offshore schools.

\section{Entry Mode Choices}

\subsection{Transaction Cost Economics}

TCE predicts comparative institutional efficiency among market, hierarchy, and hybrid organising forms in exchanging assets (Coase, 1937; Williamson, 1979; Brouthers \& Brouthers, 2003). Because of bounded rationality, opportunism, and the exchange frequency, the level of asset specificity determines the choice of mode in organising forms in pursuing efficient governance between exchange partners (Williamson, 1979, 1981). A large number of past studies found that high level of asset specificity demanded the choice of high control mode in order to govern exchange process in an efficient manner (Anderson \& Gatignon, 1986; Brouthers \& Brouthers, 2003; Brouthers \& Nakos, 2004; Cosco, 2011; Elango \& Sambharya, 2004; Hayden \& Thompson, 1995; Hennart, 1988; Horvat, 1999; Kolk, Van Tulder, \& Kostwinder, 2008; Ramaswami \& Agarwal, 2000; Scheutze \& Li, 2008; Wacziarg \& Welch, 2008; Wen, 2005; Zhao \& Decker 2003). In addition, there is sufficient evidence for entry mode choices regarding the level of specific assets possessed by MNEs upon FDI decisions (Bartlett, 2010; Brouthers \& Brouthers, 2003; Chen \& Hu, 2002; Cosco, 2011; Hayden \& Thompson, 1995; Hayden \& Thompson, 1995; Tan, 2009; Zhao \& Decker, 2003).

In this climate, transaction costs for offshore schools tends to be high given the negotiation amongst offshore school MNEs and required adherence to government regulations pertaining to educational curricular standards and outcomes. The specific assets possessed by offshore school MNEs include land investments for the educational institute, the physical buildings of instruction, facilities for instruction, materials for learning including books and equipment, government-licenced teachers and administrators from the home country brought over to deliver curricula, periodic inspections for checking compliance, and local-foreign investors participating in the capitalisation of the enterprise, which are hardly to re-deploy if the FDI of educational curricular standards and outcomes do not align with the home-country authorities. For example, regardless of the entry mode utilised, there must be a physically manifested set of classrooms exclusively owned by the school. Another example is that the school can prove that their teachers and administrators have the legal capacity to instruct on the home-country authority's curriculum. A final example is the inspectors are recognised by the home-country authority and they can verify that the school they observe meets accepted criteria for school operations. Hence,

Hypothesis 1: The level of asset specificity is positively associated with the choice of high control mode. 


\subsection{Institutions}

Institutions can be examined by their changes and impact on economic performance over time. There is a distinction between institutions and organisations. Both form the structural framework that supports activities of exchange and interaction but they are not the same (North, 1990). Institutions can be considered the rules of the game and organisations can be considered the players. The purpose of the rules, or of the institutions, is to define the way that the game is played. Political parties, religious institutions, schools, labour unions, corporations or government agencies are among some major organisations as the agents for institutional change with emphasis on the interaction between the rules and the players. Competitive pressure leads to the elimination of inefficient institutions, which causes the radically different performance of economies over long periods of time (North, 1990, 2005). Firms make choices based on costs and benefits with many of the benefits based on subjective perceptions, and mostly, based on imperfect information. Resultant institutional changes often have unintended consequences that are not always the optimal choice for the organization (Austin \& Seitanidi, 2012). The systematic investment in skills and knowledge and their application to an economy suggests a dynamic evolution of that economy that entails a specific set of institutional characteristics (North, 1990). This adaptive efficiency under the institutional framework directs the process of learning and the development of knowledge leading to decision-making (Kolk, Van Tulder, \& Kostwinder, 2008). Studies found that institutions affect the FDI entry mode choices when MNEs tend to choose high control mode entering those countries with unfamiliar institutions (Brouthers \& Brouthers, 2003; Chen \& Hu, 2002; Hill \& Jones, 2007; North, 1990) or with uncertain institutional environments (Dunning, 1998; Horvat, 1999; State Council, 2003).

However, offshore school MNEs must abide by the rules and regulations of the home country institutions of the educational authorities. Regardless of FDI host countries, formal and informal rules of institutions are the interplay between the education authorities, the physical institutes of instruction, and relationships between the investor companies in the home country contexts. Except the motives of FDI locations of offshore school investments, Host country institutions do not matter in this situation because they are not the prime regulators of the curricula being offered. They do not provide a means for the students to graduate to overseas universities. They do not have influence on the home country institution and don't affect the curricula. Thus, host country institutions play a neutral role in the offshore Sschools, and are not important factors in this industry. Hence,

Hypothesis 2: The home country institutions influence the choice high control mode.

\section{Methodology}

The objective of this study is to investigate the choice of offshore schools entry mode and the relationships between asset specificity and institutions. A quantitative approach is taken via information from academic papers, government documents, anecdotal evidence from secondary sources, and specific school primary sources. A quantitative approach is effective when identifying, acquiring and collecting data from companies and offshore schools. We explore all necessary information from industry and regulatory practitioners, and extract the dataset for this study.

English-speaking countries dominating this global business relates to the obvious nature of the English language being the international 'lingua franca.' It is logically more desirable to obtain a diploma from an English-speaking country than, say, from a French or Spanish or Chinese or Hindi-speaking country. As such, the institutes of English-speaking countries, namely the educational, scientific, industrial and professional standards, are considered "world class" (BCMOE, 2012). For this reason, customer and student demand gravitates towards diplomas from English-speaking jurisdictions (BCCIE, 2013). It was decided to simplify the approach of selecting parent companies by narrowing the search to countries with English-speaking majority populations. These countries were, in alphabetical order, Australia, Canada, New Zealand, South Africa, the United Kingdom, and the United States of America. Of these, only Canada, Britain and the USA cleared the requirements of having parent companies of for-profit offshore schools.

Primary sources, such as inspection reports and government documents, had to state the details of the school operations, including comments on resources, regulatory adherence, faculty turnover and any possible mention of student population growth or decay. Inspection reports from the government of the Canadian province of British Columbia, as well as Ontario, New Brunswick, Nova Scotia and Manitoba, shed light on inspector opinions. Non-Canadian sources, such as American overseas education agencies and British Ministry of Education, also displayed similar information. These sources would complement website data and help give a fuller picture of offshore school entry mode. Secondary sources were invaluable when identifying problems with the operational or business side of the offshore school evaluation. These secondary sources included newspaper and news magazine reports dealing with government-offshore school interactions, and employee and educational 
standards conflicting with productivity. Also, there were numerous websites for interested parents regarding qualities of overseas schools, and sections therein logging comments and ratings for each school were invaluable. These websites helped in the construction of a rubric regarding school performance our dataset. Once the analysis of gathered research and practitioner information was completed, compiling primary source data on offshore schools was conducted for SPSS analysis by using the logistic regression.

We formulated the dataset related to offshore schools via the following conditions. First, any non-profit school or company would be immediately excluded. Second, the sources had to explicitly state that they carried out the curricular responsibilities of home education authorities, or else be excluded as well. Third, the school's primary source had to display the following information: lists or numbers of faculty, lists or numbers of staff, numbers of students attending, a history of the school for ascertaining age and other information, the structure of the school's operations for identifying entry mode, the home education authority, the host education authority, corporate/ firm information about the parent company, and student-teacher ratios.

The websites examined were official websites of offshore schools. Each section of the website was examined by reading the information carefully to uncover the answers to the questions above. For faculty and staff, there had to be mention of numbers of these. Individual photos of these personnel were invaluable for doing a headcount. There had to be specific numbers of students attending, or a mention of class size to multiply it with number of teachers to arrive at a number of student population. A section on school history had to mention year of establishment. A description of how the school operates and where it operates was needed for ascertaining entry mode. A specific home education authority needed to be mentioned and any relevant host education authority. A mention of the governing board of the business side of the company was essential for confirming the operation as an offshore school. There were a total of 203 offshore schools (see appendix A) found to fit the criteria, including 19\% from the US, 66\% from Canada, and 15\% from UK. Their FDI countries were mostly in China (72\%), with others in the host countries listed in appendix B. All the data were collected from the above available sources in 2013.

\subsection{Variables}

\subsubsection{Dependent Variable: Entry Mode Choice}

The entry mode is the FDI decision of choice upon the difference in degree of risk they present, the control and commitment of resources they require and the return on investment they promise (Zhao \& Decker, 2003). In this study, two major categories of offshore school FDI entry mode are classified: equity and non-equity. The former includes licensing and franchising mode of offshore school FDIs, and the latter includes joint venture, greenfield, and brownfield investment. Brownfield FDIs circumvent the need to design and construct new buildings; rather the company can purchase and refit existing infrastructure to their needs, which can save capital costs normally associated with greenfield FDIs (Cheng, 2006; Meyer \& Estrin, 2001).

\subsubsection{Explanatory Variable: Asset Specificity}

In the offshore school context, asset specificity is captured by the following six measures in this study.

1) Faculty size: The faculty of a school includes the administration and teaching staff. The administration is the host country principals, home country principals, and officials from the business component of the company. Faculty size was coded simply by the number of faculty stated to be employed on site. This ranged from 5 to more than 200 members.

2) Support staff size: The support staff includes the office secretaries, janitors, personnel from the business component of the school, security guards, student caretakers and other miscellaneous positions. Support staff size was coded simply by the number of staff stated to be employed on site. This ranged from 5 to more than 50 members.

3) Number of departments: Each department oversees the delivery of a single school subject, such as English, History, Chemistry, Mathematics, Physical Education, and so forth. Departments can also regard Counselling, Special Education, administration, and so on. The number of departments may vary between each school, depending on the number of subjects taught, the required subjects dictated by the home education authority, and instructional subjects required by the local education authority. This number was given a simple range from 5 to 12 departments.

4) Offshore school as feeder school to specific university in the home country: This falls into two categories: yes and no. If yes, the offshore school has an arrangement with a post-secondary institution, such as a university that the students will graduate directly into. If no, the offshore school does not have an 
arrangement with a post-secondary institution (Robinson, Wei, Gong, \& Schwalb, 2010). This variable was then coded yes as dummy 1 .

5) Number of students: The number of students means those students who have officially enrolled at the start of the school year, usually in August or September of each year. This number can fluctuate depending on late enrollments not recorded on the website, or students dropping out or quitting school due to academic, financial or familial circumstances (Findlay, 2011). Owing to the extreme fluctuations in numbers of students between schools, these numbers were calculated logarithmically to produce data samples better for use by analysis programs.

6) Student/Faculty Ratio: This ratio refers to the number of students per teacher. The higher the number, the more students the teacher instructs, and vice versa. This ratio has two implications for high numbers. First, there are a large number of students paying to attend the school, therefore the classes are full. This is positive. Second, it also means that there could be a poor level of teacher-student relationship negatively impacting on student academic success. Alternatively, a low ratio means the school is not attracting 'customers,' or the school is remedying low student scores by hiring additional teachers.

\subsubsection{Explanatory Variable: Home Country Institutions}

Home Education Authority: A home education authority is a Ministry or Department of Education of a home-country government. It can also be an individual school district or a consortium of educational authorities, but the home education authority still has precedence over them. This variable was then coded 1 through 11 . Owing to the constitutional makeup of Canada's government, where there is no single federal Ministry of Education but rather 10 different provincial Ministries. British Columbia was numbered 1, Alberta 2, Manitoba 3, Ontario 4, New Brunswick 5, and Nova Scotia 6. The provinces of Saskatchewan, Quebec, P.E.I. and Newfoundland didn't have Offshore Schools and were thus not numbered. American Departments of Education were grouped from 7 through 9. Lastly, the United Kingdom was grouped as 10. All other authorities were grouped as 11 . The distribution of home country education authorities are listed in table 1 . On the other hand, the local education authority is not included as a variable because the local country is not able to set standards for offshore school operations, neither can it own the authority for the purpose towards higher degree of education upon diploma granted.

Table 1. Distribution of home country education authorities ( $\mathrm{N}=203)$

\begin{tabular}{lcc}
\hline Valid & Frequency & Percent \\
\hline Alberta MOE* & 6 & 2.9 \\
British Columbia MOE* & 45 & 22.2 \\
Manitoba MOE* & 9 & 4.4 \\
Michigan University & 1 & 0.5 \\
Minnesota DOE & 8 & 3.9 \\
New Brunswick MOE* & 10 & 4.9 \\
Nova Scotia MOE* & 19 & 9.3 \\
Ontario MOE* & 26 & 12.7 \\
Pennsylvania DOE & 1 & 0.5 \\
United Kingdom MOE & 28 & 13.7 \\
United States DOE & 28 & 12.3 \\
Not Specified** & 25 & 12.1 \\
Total & 35 & 100.0 \\
\hline
\end{tabular}

Note. $\mathrm{MOE}=$ Ministry of Education; DOE = Department of Education;

*Canadian provincial Ministries. These altogether form $56.7 \%$ of total sample.

**Home country education authority mentioned but not specified.

\subsubsection{Control Variable: Years Operating}

This pertains to the number of years that the school has operated, up to the time of late 2013. The distinction 
between incorporation of the enterprise and actual initial operations of the local institution is often unclear, so liberty was taken with the stated age of the operation. In the case of closed offshore schools, the age refers to total years of operation before closure. This variable was not deemed important to code, and thus was not done so.

\subsection{Analytic Results}

Analysis of the offshore school data of sample size 203 was taken. SPSS 20.0 was utilised. All variable descriptors previously mentioned that can potentially carry numeric values attached to them were given a summary analysis. They were analysed regarding their minimum and maximum values, and their mean and standard deviation as shown in table 2. Table 3 shows the correlations of all variables. There is only one correlation, faculty size and number of students (ln), above 0.7 .

Table 2. Descriptive analysis $(\mathrm{N}=203)$

\begin{tabular}{lcccc}
\hline & Min & Max & Mean & St. Dev. \\
\hline High Control & 0.00 & 1.00 & 0.86 & 0.35 \\
Asset Specificity & & & & \\
$\quad$ Faculty Size & 2.00 & 280.00 & 56.23 & 64.86 \\
$\quad$ Staff Size & 0.00 & 80.00 & 9.71 & 10.39 \\
No. of Departments & 1.00 & 12.00 & 7.86 & 2.99 \\
Feeder Schools & 0.00 & 1.00 & 0.11 & 0.31 \\
Student (ln) & 2.77 & 8.01 & 5.70 & 1.32 \\
$\quad$ Std/Fac Ratio & 2.70 & 65.00 & 10.67 & 5.94 \\
Institutions & & & & 3.17 \\
Home Ed. Authority & 1.00 & 11.00 & 4.40 & \\
Control Variables & & & & 9.72 \\
$\quad$ Years in Operation & 1.00 & 112.00 & 9.81 & \\
\hline
\end{tabular}

Table 3. Correlations on all variables $(\mathrm{N}=203)$

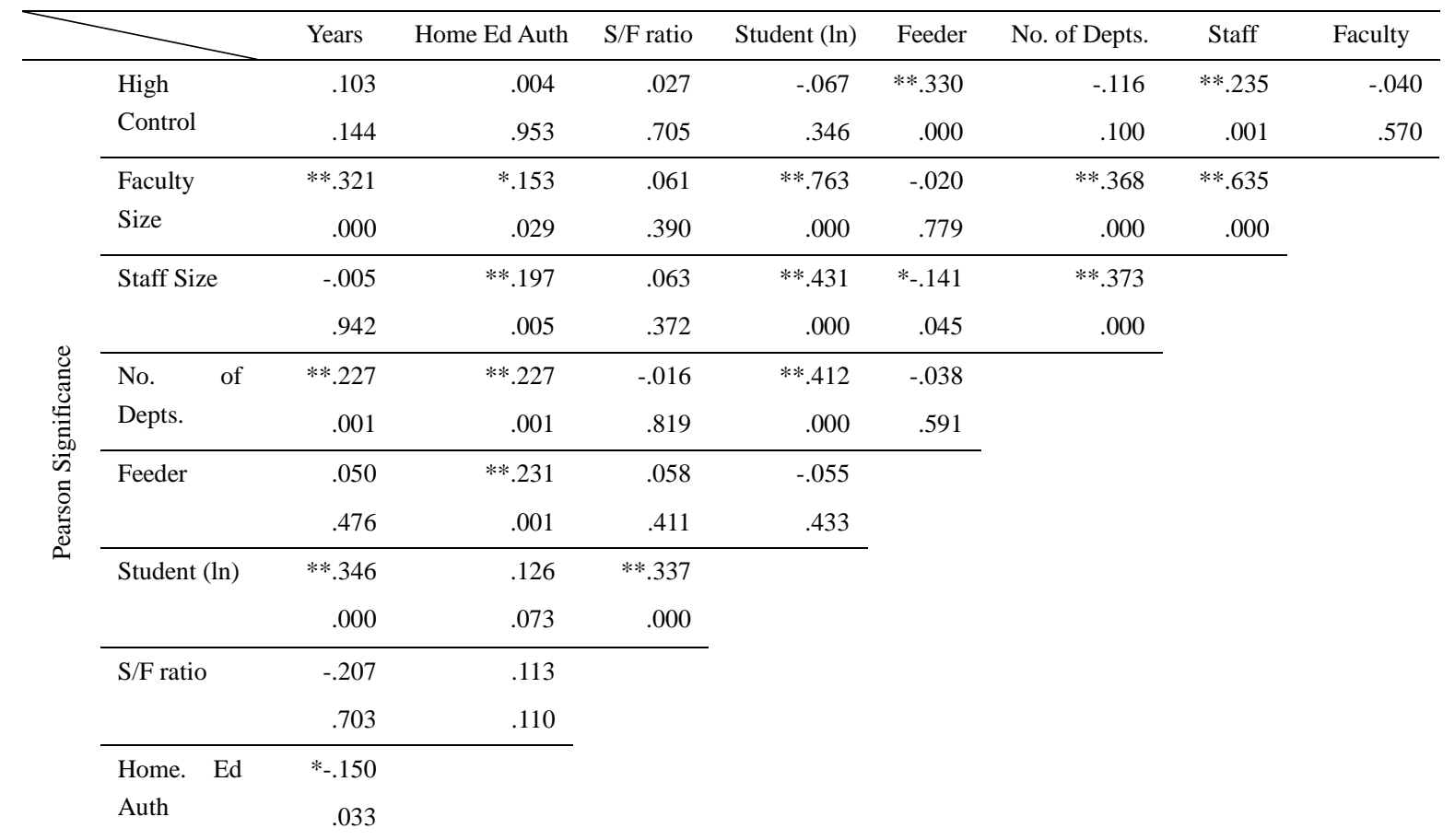

Note. Significance levels: $0.01(* *), 0.05(*)$. 
Table 4 shows regression on high control entry mode. All numbers below 0.100 are discovered for the following regressions: Staff Size, Feeder Schools, and Home Education Authority. Thus, H1 is partially supported by staff size and feeder schools. However, the signs of these two measures of asset specificity influence in the opposite ways. Our findings align with the past studies that different types of asset specific matter (Masten, Meehan, \& Snyder, 1989; Williamson, 1991). Since an offshore school's 'product' is students with high school diploma, it is reasonable that human resources need to be invested in as specific assets. While faculty size does not influence the choice of high control mode, the larger the staff size, the less intention to choose high control mode in offshore school FDI. The more support staff on site, for example secretaries, education assistants, maintenance crew, bus drivers and executive personnel, means the better able the institution is able to put resources towards meeting student needs, but not in high control mode. Probably they can be hired mostly from the local markets, without less specific requirements in offshore school human resource qualifications.

Meanwhile, feeder school is highly associated in choosing a high control mode. Feeder schools have both regulatory demands from home education authorities and contractual demands from the university or institution it is obligated to send graduated students to. Particularly for feeder schools as a function of the design pertaining to its relation to the parent company post-secondary institution it is designed to contribute graduated students to. For the guaranteed linkage between feeder offshore school and its parent, the asset specificity is not only captured by the specificity of human resources in students, but also by the temporal connections. It must have a "pull" exerted on it by a post-secondary institution by which it is contractually mandated to supply new students to.

On the other hand, $\mathrm{H} 2$ is supported. This would indicate that the Home Education Authority was instrumental as a regulating agency on the overall quality and success of the school regarding the FDI mode of choices. It serves as an anchor or catalyst for the other variables to exist in these schools. Without the regulations each offshore school was required to adhere to, these schools would not have the relevance to provide a foreign high school diploma. As for the Home Education Authority, they are the most active regulatory partner in the enterprise, as they are directly responsible for the accreditation of curricular standards. It would seem that this is occurring not out of a lack of direct relation to the students, but more to the productive processes that the Home Education Authority have regulative powers over. Also, since the students are the 'output' for the operation, the focus is on the essential materials and infrastructure needed for the successful service towards granting these students their high school diplomas.

Table 4. Regression on high control mode $(\mathrm{N}=203)$

\begin{tabular}{lcccccc}
\hline & $\beta$-dist. & S.E. & Wals & Df & Significance & $\operatorname{Exp}(\beta)$ \\
\hline Faculty Size & .019 & .012 & 2.373 & 1 & .123 & 1.019 \\
Staff Size & $\mathbf{- . 0 8 7}$ & .040 & 4.795 & 1 & $\mathbf{. 0 2 9}$ & .916 \\
No. of Departments & -.080 & .088 & .825 & 1 & .364 & .923 \\
Feeder Schools & $\mathbf{2 . 3 5 6}$ & .638 & 13.641 & 1 & $\mathbf{. 0 0 0}$ & 10.552 \\
No. of Students (ln) & -.525 & .394 & 1.773 & 1 & .183 & .591 \\
S/T Ratio & -.029 & .042 & .486 & 1 & .486 & .971 \\
Home Ed. Authority & $\mathbf{. 1 8 0}$ & .105 & 2.940 & 1 & $\mathbf{. 0 8 6}$ & 1.197 \\
Years in Operation & .058 & .057 & 1.033 & 1 & .309 & 1.060 \\
Constant & 2.694 & 2.234 & 1.454 & 1 & .228 & 14.789 \\
\hline
\end{tabular}

Note. Numbers in Bold denote related Beta-distribution with significance.

\section{Discussion}

Our findings can be interpreted as a function of the type of entry mode utilised by offshore schools. In the offshore school contexts, feeder schools and home country authority are among the major importance in choosing FDI entry mode.

\subsection{Asset Specificity of Feeder Schools}

The conditions for asset specificity are two-fold. First, any operation that wants to grow and succeed must have three components: a Home Education Authority, a contract with a specific post-secondary institution (or academic conglomerate), and a company that is able to provide capital and financing for the project. In other 
words, being a feeder school is essential to an offshore school's viability. Our findings show that feeder school is highly associated in choosing a high control mode in entering foreign market in the offshore school contexts. Feeder schools have their market in terms of guaranteeing the direct connection of their graduates with the specific higher-level educational institutions in the home country. This 'one-on-one' strategy is the key determinant in terms of asset specificity upon a high control mode FDI. For the guaranteed linkage between feeder offshore school and its parent, the asset specificity is not only captured by the specificity of human resources in students, but also by the temporal connections. Such offshore schools from English-speaking countries provide predominant gateways for students in the host countries like China with high incentives of a $100 \%$ sure outcome, which is going to study at a higher education institution in an English-speaking country. On the other hand, feeder offshore school parents invest in high control mode may minimize the risk on receiving any inappropriate or any inconsistent trained students in the home country institutions. The asset specificity in feeder schools implies that in the offshore school business, both human resource specificity and temporal specificity play an important role in determining FDI entry mode choices.

\subsection{Home Country Authority}

As per institutional theory, home educational authorities provide the rules and regulatory structure by which the school organisations operate in. Dissimilar with most of the prior MNE research on the influence of host country institutions on entry mode choices in other industries (e.g., Agarwal \& Ramaswami, 1992; Brouthers, 2002; Hill, Hwang, \& Kim, 1990; Kwon \& Konopa, 1992; Meyer, 2001), offshore schools require the regulatory scaffolding of these institutions according to the home country authorities, including the government, universities and other post-secondary institutes. Such support systems not only involve rules and oversight, but also financial and logistical means. As long as the host countries, mainly non-English markets, own a strong potential of English-speaking educations as well as higher education demands in those English-speaking countries, the host country authority normally does not perform an active role in offshore school businesses (Scheutze \& $\mathrm{Li}, 2008$ ).

\subsection{Performance Implications}

The fit of entry mode choice in correlation to its determinants should further imply a superior performance in offshore school FDIs. We further obtain a performance assessment by using means of reading home country education authority inspection reports, comments by parents regarding schools on websites dedicated to international and offshore schools, and anecdotes by teachers, students and clients collected by journalists researching offshore schools. We categorised the 203 offshore schools into seven levels of performance:

1) Performance scale 7: very good, expanding: An offshore school is doing very well and has expanded or will expand into two or more campuses.

2) Performance scale 6: very good, growing: An offshore school is doing very well and its student population is growing. This means the company has a constantly expanding inflow of capital from consumers. It is not yet at the point of 'mitosis' where it can split into multiple campuses.

3) Performance scale 5: good, stable: An offshore school is doing very well and its student population is stable. This means the company has a constant inflow of capital from consumers. The school was at the "Very good, growing" stage a few years ago but has levelled off and has reached maximum growth. There are no apparent intercultural issues. The population may gain or lose a few students per year but overall remains constant. The school may yet expand again, but overall has reached maturity.

4) Performance scale 4: good, some comments: An offshore school is doing very well and its student population is stable. The population may gain or lose a few students per year but overall remains constant. The school may yet expand again, but overall has reached maturity. However, there are concerns about student resource availability, curricular standards and working conditions. There are some apparent intercultural issues.

5) Performance scale 3: bad, many comments: An offshore school is experiencing difficulties with student resource availability, curricular standards, working conditions and capital inflow. Its student population is stagnant, or too small for investment returns. There are numerous concerns about student resource availability, curricular standards and working conditions. There are apparent intercultural problems.

6) Performance scale 2: bad, certification revoked: An offshore school is experiencing difficulties with student resource availability, curricular standards, working conditions and capital inflow. Its student population is too small for investment returns. There are numerous concerns about student resource availability, curricular standards and working conditions. Intercultural issues were not overcome. The home education authority has therefore cancelled its license. The school will cease operations in the near future. 
7) Performance scale 1: closed: An offshore school experienced difficulties with student resource availability, curricular standards, working conditions and capital inflow. Its student population was too small for sustainable investment returns. Intercultural problems were not overcome. The school closed.

Figure 1 demonstrates the performance categories in terms of the home countries. Accordingly, we did a further fit analysis for performance implications. The ideal performers were cut at the leading 23 high performing schools, with rating performance scale above and including 5 . We then used the top performed offshore school data to re-regress the ideal equation of entry mode choice, followed by a comparison of the ideal data with the full data by using ANOVA analysis. We found the top performers averaged a rating of 5.57, significantly higher than the rest of the data, with the averaged rating of 4.93. The F-value is 5.265 with a significance level at 0.023 . Therefore, our model of asset specificity and home country institutions do influence the choice of entry mode in the offshore school FDI context, therefore the fit in the model leads to superior performance.

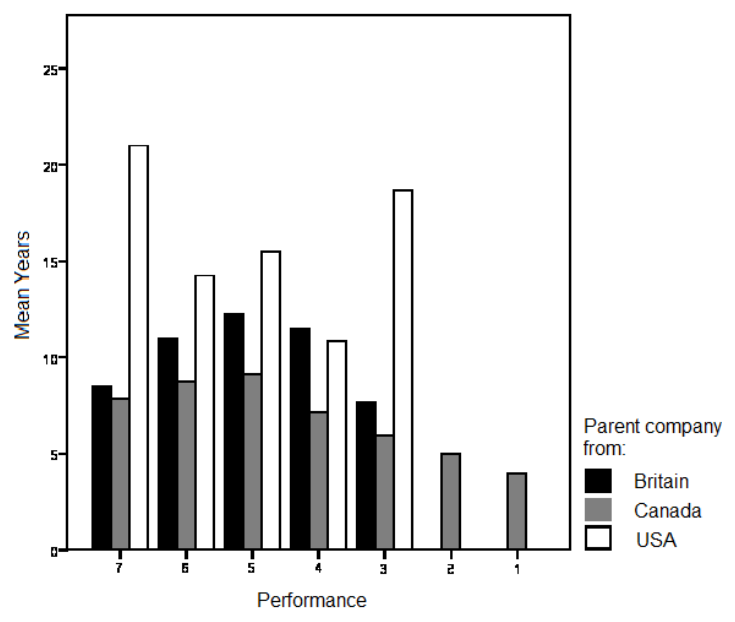

Figure 1. Performance of school by country and years operating

Our study provides theoretical implications in explaining FDI entry mode choices from the explanations asset specificity and home country institutions. In the current empirical context of offshore school FDI from English-speaking countries, the strategy of the feeder school FDI is not only important in choosing a high control mode, but also shows the major types of asset specificity in human resources and temporal dimensions. Moreover, the home country institution is particularly important for an offshore school to choose an entry mode, whereas most IB studies focused on the host country institutions in an FDI entry mode choice.

In addition, our study provides practical implications for the offshore school FDIs from an MNE perspective. For many higher education institutions in the English-speaking countries pursuing a growth model, international expansion through establishing offshore schools in overseas markets becomes an option. However, the FDI mode of choice should be cautious in alignment with whether to set up a feeder school and support staff size. Moreover, the home country authority matters in entry mode choice decisions. Given the current economic situation in North America, many higher education institutions might take potential overseas markets into consideration via offshore school businesses.

\subsection{Limitations and Future Research}

There is no data available to track student scores per teacher, and no data on teacher performance as a function of student scores. This is important when considering the quality of the product or service the firms are producing. The level of faculty and staff turnover was not able to be discerned. This would be an indication of service quality and investment by the firm in the professional and personal well-being of the human resources. Related to this is the student retention rate. Are they staying for the duration of the program, or are many leaving before graduating due to satisfaction levels, financial situations and other kinds of issues? These further kinds of data are currently unavailable. Future research might take further investigation into these firms' financial picture and firm viability. In addition, questionnaire surveys could be conducted of the corporate executives, investors, education authority personnel, government agents, administrative staff, school support staff, faculty and even the students. Such efforts in future research can further clarify the offshore school business with its potential in the 
IB empirical context.

\section{Conclusion}

This paper studies offshore school FDIs from English-speaking countries and their entry mode choices. Offshore schools are for-profit, private sector educational services established for granting home government recognised high school diplomas to students in an overseas country. They are the MNEs in the educational contexts. By creating a dataset of 203 offshore schools from Canada, the USA, and the UK from multiple sources, we found that asset specificity and home country institutions play roles in FDI entry mode choices. Particularly, the feeder school is highly specific and demands a high control mode, whereas the supporting staff size is negatively associated with a high control mode choice. Home country authorities influence mode of choices in the offshore school FDI decision, which implies that differential regulations on education systems and standards exist between institutions even within the single home country. Our study provides implications on theories and practices in the offshore school business context.

\section{Acknowledgements}

We thank the reviewers' and participants' comments from 2014 Annual Meeting of Academy of International Business.

\section{References}

Agarwal, S., \& Ramaswami, S. N. (1992). Choice of foreign market entry mode: Impact of ownership, location and internalization factors. Journal of International Business Studies, 23(1), 1-27. http://dx.doi.org/10.1057/palgrave.jibs.8490257

Austin, J. E., \& Seitanidi, M. M. (2012). Collaborative value creation: A review of partnering between nonprofits and businesses: Part I. Value creation spectrum and collaboration stages. Nonprofit and Voluntary Sector Quarterly, 4l(5), 726-758. http://dx.doi.org/10.1177/0899764012450777

BC Council for International Education. (2011). 2011 Chinese students study abroad forecast. Retrieved September 25, 2013 from http://www.bccie.bc.ca

BC Council for International Education. (2013). Developing and managing study abroad programs. Retrieved September 25, 2013 from http://www.bccie.bc.ca

BC Council for International Education. (2013). Marketing BC education. Retrieved September 25, 2013 from $\mathrm{h} t t p: / / w w w . b c c i e . b c . c a$

BC Ministry of Education. (2013). Offshore transition guidelines. Government of British Columbia.

Brouthers, K. D. (2002). Institutional, cultural and transaction cost influences on entry mode choice and performance. Journal of International Business Studies, 33(2), 203-221. http://dx.doi.org/10.1057/palgrave.jibs.8491013

Cheng, Y. M. (2006). Determinants of FDI mode choice: Acquisition, brownfield, and greenfield entry in foreign

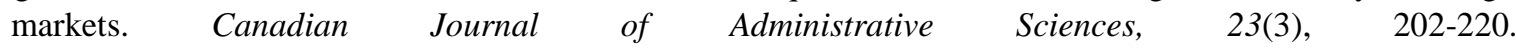
http://dx.doi.org/10.1111/j.1936-4490.2006.tb00627.x

Coase, R. H. (1937). The nature of the firm. Economica, 4(16), 386-405. http://dx.doi.org/10.1111/j.1468-0335.1937.tb00002.x

Cosco, L. (2011). Canadian overseas schools: A unique approach to the export of Canadian education. Asia-Pacific Foundation.

Das, D. K. (2004). Regionalism in global trade. Cheltenham, UK: Edward Elgar. http://dx.doi.org/10.4337/9781845421458

Dunning, J. H. (1998). Location and the multinational enterprise: A neglected factor? Journal of International Business Studies, 29(1), 45-66. http://dx.doi.org/10.1057/palgrave.jibs.8490024

Dunning, J. H. (1988). The eclectic paradigm of international production: A restatement and some possible extensions. Journal of International Business Studies, 19(1), 1-31. http://dx.doi.org/10.1057/palgrave.jibs.8490372

Findlay, S. (2011). Cashing in on foreign students. Retrieved from http://www.macleans.ca/education/uniandcollege/cashing-in-on-foreign-students-2/

Hill, C. W. L., Hwang, P., \& Kim, W. C. (1990). An eclectic theory of the choice of international entry mode. Strategic Management Journal, 11(2), 117-128. http://dx.doi.org/10.1002/smj.4250110204 
Jiang, N. Q., \& Feng, H. (2006). New patterns of China's education opening up. China Education Daily.

Kolk, A., Van Tulder, R., \& Kostwinder, E. (2008). Business and partnerships for development. European Management Journal, 26(4), 262-273. http://dx.doi.org/10.1016/j.emj.2008.01.007

Kuehn, L. (2002). B.C. government promotes privatization and a market approach to education. British Columbia Teachers' Federation.

Kwon, Y. C., \& Konopa, L. J. (1993). Impact of host country market characteristics on the choice of foreign market entry mode. International Marketing Review, 10(2), 60-76. http://dx.doi.org/10.1108/02651339310032552

Masten, S. E., Meehan, J. W. Jr., \& Snyder, E. A. (1989). Vertical integration in the U.S. auto industry: A note on the influence of transaction specific assets. Journal of Economic Behavior \& Organization, 12(2), 265. http://dx.doi.org/10.1016/0167-2681(89)90059-0

Meyer, K. E., \& Estrin, S. (2001). Brownfield entry in emerging markets. Journal of International Business Studies, 32(3), 575. http://dx.doi.org/10.1057/palgrave.jibs.8490985

Meyer, K. E. (2001). Institutions, transaction costs, and entry mode choice in Eastern Europe. Journal of International Business Studies, 32(2), 357-367. http://dx.doi.org/10.1057/palgrave.jibs.8490957

North, D. C. (1990). Institutions, institutional change and economic performance. Cambridge University Press. http://dx.doi.org/10.1017/cbo9780511808678

North, D. C. (2003). Understanding the process of economic change. Princeton (USA) and Oxford (UK): Princeton University Press.

Robinson, S. N., Wei, J., Gong, Y., \& Schwalb, M. (2010). Higher education and foreign schools in China. Journal of College and University Law, 36(2), 363-398.

Scheutze, H. G., \& Li, S. (2008). Canadian offshore schools in China. Asia Pacific Foundation of Canada.

Schuetze, H. G., Kuehn, L., Davidson-Harden, A., Schugurensky, D., \& Weber, N. (2011). Globalization, neoliberalism and schools: The Canadian story. In C. A. Torres, L. Olmos, \& R. Van Heertum (Eds.), In the Shadow of Neoliberalism: Thirty years of Educational Reform in North America. Oak Park, IL: Bentham Books. Retrieved from http://www.benthamscience.com/ebooks/contents.php?JCode=9781608052684

Singh, A. (2010). Globalism, neo-liberalism, public schools and higher education: Is your academic institution moving toward corporate model under globalism and neo-liberalism: What is being said and done around you and what should you observe, say and do? Memorial University of Newfoundland.

State Council of the People's Republic of China. (2003). Regulations of the People's Republic of China on Chinese-foreign cooperation in running schools. China Education Daily. 24 March 2003.

Steffenhagen, J., \& Sun, V. (5 May 2013). B.C. orders closure of one of its offshore high schools. Retrieved from http://www.vancouversun.com/orders+closure+offshore+high+schools/8341124/story.html

Tan, Z. (2009). Internationalization of higher education in China: Chinese-foreign cooperation in running schools and the introduction of high-quality foreign educational resources. International Education Studies, 2(3). http://dx.doi.org/10.5539/ies.v2n3p166

Waters, J. L. (2006). Emergent geographies of international education and social exclusion. Antipode, 38(5), 1046-1068. http://dx.doi.org/10.1111/j.1467-8330.2006.00492.x

Wen, J. (2005). Chinese-foreign cooperation in running schools expects high-quality resources. China Youth Daily. 1 March 2005.

Williamson, O. E. (1979). Transaction-cost economics: The governence of contractual relations. Journal of Law and Economics, 22(2), 233-261. http://dx.doi.org/10.1086/466942

Williamson, O. E. (1981). The economics of organization: The transaction cost approach. American Journal of Sociology, 87(3), 548-577. http://dx.doi.org/10.1086/227496

Williamson, O. E. (1985). The economic institutions of capitalism. New York, NY: Free Press.

Williamson, O. E. (1991). Comparative economic organization: The analysis of discrete structural alternatives. Administrative Science Quarterly, 36(2), 269-296. http://dx.doi.org/10.2307/2393356

Xiang, B., \& Shen, W. (2009). International student migration and social stratification in China. International Journal of Educational Development, 29(5), 513-522. http://dx.doi.org/10.1016/j.ijedudev.2009.04.006 
Zhao, X., \& Decker, R. (2004) Choice of foreign market entry mode: Cognitions from empirical and theoretical studies. University of Bielefeld.

\section{Appendix A}

\section{List of Offshore Schools, with Number of Campuses and Website Links}

\begin{tabular}{|c|c|c|}
\hline School Name & Campuses & School Website \\
\hline 3e International School & 1 & www.3eik.com \\
\hline Abu Dhabi Grammar School (Canada) & 1 & www.agsgrmmr.sch.ae \\
\hline Academia Cotopaxi & 1 & www.cotopaxi.k12.ec \\
\hline Access International Academy - Ningbo & 1 & www.aian.org.cn \\
\hline AFNORTH International School in the Netherlands & 1 & www.afnorth-is.com \\
\hline American International School of Guangzhou & 1 & www.aisgz.org \\
\hline American School of Belo Horizonte & 1 & www.eabh.com.br \\
\hline American School of Paris & 1 & www.asparis.org \\
\hline Anhui Concord College of Sino-Canada (ACCSC & 1 & www.accsc.com.cn \\
\hline BCA Canada & 1 & www.bcacanada.org \\
\hline BCCIS & 1 & www.bccis.net \\
\hline Beijing BISS International School & 1 & www.biss.com.cn \\
\hline Beijing Concord College of Sino-Canada (BCCSC) & 1 & www.ccsc.com.cn/english \\
\hline Beijing No. 25 Middle School & 1 & www.bj25schooledu.com.cn \\
\hline Beijing Shuren-Ribet Private School & 1 & www.shurenribet.org \\
\hline Beijing World Youth Academy & 1 & www.ibwya.net/ \\
\hline BIS Canada & 1 & www.biscanada.org \\
\hline Boren Sino - Canadian School & 1 & www.borenschool.com \\
\hline Britannica International School Shanghai & 1 & www.britannicashanghai.com \\
\hline British Columbia International School, Bangkok & 1 & www.bcisb.net \\
\hline CamBridge Elementary School of Foreign Language & 1 & www.internationalschool.info \\
\hline Canada BC International School & 1 & www.bccis.net \\
\hline Canada Changchun Shiyi Secondary School & 1 & www.cicic.ca \\
\hline Canada Hainan Secondary School & 1 & www.canadahainanss.com \\
\hline Canada Hefei No. 1 Secondary School & 1 & www.hfbh.gov.cn \\
\hline Canada Kunming No. 10 Secondary School & 1 & www.cicic.ca \\
\hline Canada Langfang Secondary School & 1 & www.gdjzx.com \\
\hline Canada Maple International School & 1 & www.cmis.kr \\
\hline Canada Qingdao Secondary School & 1 & www.csee.ca \\
\hline Canada Shandong Secondary School & 1 & www.csee.ca \\
\hline Canada Weifang Secondary School & 1 & www.canadaweifang.com \\
\hline Canada Xindu Secondary School & 1 & www.xdyz.net/english \\
\hline Canada Zibo No. 11 Secondary School & 1 & www.cicic.ca \\
\hline Canadian College Italy & 1 & www.canadiancollegeitaly.com \\
\hline Canadian Independent College Ghana & 1 & www.ghanacic.com \\
\hline Canadian International Academy & 1 & www.ciaedu.net \\
\hline Canadian International School - Yantai & 1 & www.cis-yt.cn \\
\hline Canadian International School (Abu Dhabi) & 1 & www.cisabudhabi.com \\
\hline Canadian International School (Hong Kong) & 1 & www.cdnis.edu.hk \\
\hline Canadian International School (Singapore) & 1 & www.cis.edu.sg \\
\hline Canadian International School of Beijing & 1 & www.cisb.com.cn \\
\hline Canadian International School of Egypt & 1 & www.cise-egypt.com \\
\hline
\end{tabular}




\begin{tabular}{|c|c|c|}
\hline Canadian School Guadalajara & 1 & www.canadianschool.com.mx \\
\hline Canadian Secondary Wenzhou No. 22 School & 1 & www.cinec.ca \\
\hline Canadian Trillinium School (CTS) & 1 & www.cts.edu.bd \\
\hline Canadian Trillium College (Quanzhou) & 1 & www.ctc-school.com \\
\hline Caribbean International Academy & 1 & www.carib-international.net \\
\hline Carol Morgan School & 1 & www.cms.edu.do \\
\hline CBIS & 1 & www.cbis.or.kr \\
\hline Changchun Experimental High School & 1 & www.anesl.com/schools \\
\hline Chengdu Foreign Language School & 1 & www.cfls.net.cn \\
\hline Clifford School & 1 & www.cliffordschool.org \\
\hline Colegio Canadiense & 1 & www.colegiocanadiense.edu.co \\
\hline Colegio Jorge Washington & 1 & www.cojowa.edu.co \\
\hline Colegio Roosevelt & 1 & www.amersol.edu.pe \\
\hline Colégio Santa Maria & 1 & www.colsantamaria.com.br \\
\hline Cologio Nueva Granada & 1 & www.cng.edu \\
\hline Columbia International College Taiwan & 1 & www.cict.org.tw \\
\hline Columbia International School of Japan & 1 & www.columbia-ca.co.jp \\
\hline Concordia International School Shanghai & 1 & www.concordiashanghai.org \\
\hline Daystar Academy & 1 & www.daystarchina.cn \\
\hline Delia School of Canada & 1 & www.delia.edu.hk \\
\hline Dulwich College Beijing & 1 & www.dulwich-beijing.cn \\
\hline Dulwich College Shanghai & 1 & www.dulwich-shanghai.cn \\
\hline Dulwich College Suzhou & 1 & www.dulwich-suzhou.cn \\
\hline English School attached Guangdong University of Foreign & 1 & www.gwdwx.com/html/english \\
\hline Escuela Campo Alegre & 1 & www.ecak12.com \\
\hline Etonhouse International School - Wuxi & 1 & www.wuxi.etonhouse.com.cn \\
\hline Georgetown International Academy & 1 & www.georgetowninternational.org \\
\hline Grand Canadian Academy - Jiaxiang & 1 & www.gcahighschool.ca/jiaxing \\
\hline Grand Canadian Academy (Hongkou, Shanghai) & 1 & www.gcahighschool.ca \\
\hline Guangzhou Huamei International School & 1 & www.hm163.com/englishvesion \\
\hline Guangzhou Nanhu International School & 1 & www.gnischina.com \\
\hline Guiyang Concord College of Sino-Canada (GCCSC) & 1 & www.giccsc.com/english \\
\hline Guiyang No. 1 High School & 1 & www.gyyz.com.cn/En \\
\hline Handan No. 1 High School & 1 & www.internationalprograms.ednet.ns.ca \\
\hline Hangzhou International School & 1 & https://hz.scis-his.net \\
\hline Hanova International Department of Bodi School & 1 & www.his-xian.com \\
\hline Harrow International School & 1 & www.harrowschool.ac.th \\
\hline Hayat Universal School (HUBS) & 1 & www.hayatschool.com \\
\hline Henan Experimental High School & 1 & www.chinatefl.com/henan \\
\hline Huamei-Bond International College & 1 & www.hm163.com \\
\hline InterAmerican Academy & 1 & www.interamerican.edu.ec \\
\hline International School of St. Lucia (ISSL) & 1 & www.stluciayp.com \\
\hline Ivy Academy & 1 & www.ivyschools.com \\
\hline Jiaxing Senior High School & 1 & www.jxgjzx.net.cn \\
\hline Jinan EtonHouse International School & 1 & www.etonhouse.com \\
\hline Karamay Senior High School & 1 & www.en.klmyedu.cn \\
\hline Lertlah School & 3 & www.lertlah.com \\
\hline Liaodong Canadian International School of China & 1 & www.cicic.ca \\
\hline
\end{tabular}




\begin{tabular}{|c|c|c|}
\hline Lincoln School & 1 & www.edline.net/pages/LincolnCostaRica \\
\hline Livingston American School & 1 & www.laschina.org \\
\hline Luoyang No. 1 High School & 1 & www.lyyg.com \\
\hline Luwan Senior High School & 1 & www.lwedu.sh.cn \\
\hline Lyford Cay International School & 1 & www.lcis.bs \\
\hline Maple Leaf Education System & 21 & www.mapleleafschools.com \\
\hline Maple Leaf International School - Trinidad and Tobago & 1 & www.mapleleaf-school.com \\
\hline Meitoku Gijuku School & 1 & www.meitoku-gijuku.ed.jp \\
\hline Middle School attached to Hebei Normal University & 1 & www.internationalprograms.ednet.ns.ca \\
\hline Morgan Rothschild Academy & 1 & www.morganrothschild.com \\
\hline Mount Saint Agnes Academy & 1 & www.msa.bm \\
\hline Nanchang No. 2 High School & 1 & www.cicic.ca \\
\hline Nanjing Foreign Language School British Columbia Academy & 1 & www.nfls.com.cn \\
\hline Nanjing-Bond International College & 1 & www.bondschoolsinternational.com \\
\hline Neuchâtel Junior College & 1 & www.njc.ch \\
\hline NOVA International Schools & 1 & www.nova.edu.mk \\
\hline Oxford International College of Changzhou & 1 & www.czoic.com \\
\hline Oxstand-Bond International College & 1 & www.oxstandbond.com.cn \\
\hline Qatar Canadian School & 1 & www.qcs.edu.qa \\
\hline Qingdao Amerasia International School & 1 & www.qingdaoamerasia.org \\
\hline Qingdao No.1 International School of Shandong Province & 1 & 1www.qiss.org.cn \\
\hline Rigo British & 1 & www.beijingrego.com \\
\hline Ritz Calilord Academy & 1 & www.calilord.com \\
\hline Saint Paul American School & 1 & www.stpaulamerican.org \\
\hline Shanghai American School & 1 & www.saschina.org \\
\hline Shanghai Fudan-Vanke Experimental Private School & 1 & www.vks.cn/english \\
\hline Shanghai High School International Division & 1 & www.shsid.org \\
\hline Shanghai Nanyang Model High School & 1 & www.nanmo.cn \\
\hline Shanghai Rego International School & 1 & www.srisrego.com \\
\hline Shanghai United International School & 1 & www.suis.com.cn \\
\hline Shenyang No. 2 High School (North Campus) & 1 & www.ccsc.cn/english \\
\hline Shenzhen (Nanshan) Concord College of Sino-Canada & 1 & \\
\hline Shenzhen Tsinghua Experimental School & 1 & www.tsinghuaschool-sz.com \\
\hline Shrewsbury International School & 1 & www.shrewsbury.ac.th \\
\hline Sino Bright Schools (9 Campuses) & 1 & www.schoolbj.com \\
\hline Sino-Canada High School & 1 & www.sinocanadahighschool.com \\
\hline SIS Canada & 1 & www.siscanada.org \\
\hline Soochow University High School - Canadian Program & 1 & www.en.sdfzcanada.com \\
\hline Springboard International School & 1 & www.sibs.com.cn \\
\hline Sunway College & 1 & www.sunway.edu.my \\
\hline Suzhou Etonhouse International School & 1 & www.suzhou.etonhouse.com.cn \\
\hline Suzhou Industrial Park Foreign Language School & 1 & www.english.sfls.com.cn \\
\hline Tangshan No. 1 High School & 1 & www.ts-edu.net.cn \\
\hline Taylor's College & 1 & www.taylors.edu.my \\
\hline The British International School, Shanghai & 1 & www.bisshanghai.com \\
\hline The British School of Guangzhou & 1 & www.bsg.org.cn \\
\hline The British School of Nanjing & 1 & www.bsn.org.cn \\
\hline The International School of Macao & 1 & www.tis.edu.mo \\
\hline
\end{tabular}




\begin{tabular}{|c|c|c|}
\hline Tianjin Rego International School & 1 & www.srisrego.com \\
\hline Tongchuan No. 1 High School & 1 & www.cicic.ca \\
\hline Trillium International School & 1 & www.trilliumtt.com \\
\hline Wellington College International Shanghai & 1 & www.wellington-shanghai.cn \\
\hline Western Academy of Beijing & 1 & www.wab.edu \\
\hline Western International School of Shanghai & 1 & www.wiss.cn \\
\hline Westminster Canadian Academy & 1 & www.cicic.ca \\
\hline Wusong Shanghai BC High School & 1 & www.educatedpanda.com \\
\hline Xingtai No. 1 High School & 1 & www.qianjingeducation.sinaapp.com \\
\hline Yang Guang Qing School Of Beijing & 1 & www.edu.gov.mb.ca \\
\hline Yew Chung International School & 5 & www.ycef.com \\
\hline Yew Wah School of Shanghai Changning & 1 & www.ywies-sh.com \\
\hline Yinghua - Bond International College & 1 & www.bondschoolsinternational.com \\
\hline YK Pao School & 1 & www.ykpaoschool.cn \\
\hline
\end{tabular}

\section{Appendix B}

Distribution of Host Country in Database $(\mathrm{N}=203)$

\begin{tabular}{|c|c|c|}
\hline Country & Frequency & Percent \\
\hline Antilles & 1 & 0.5 \\
\hline Bahamas & 1 & 0.5 \\
\hline Bangladesh & 2 & 1.0 \\
\hline Bermuda & 1 & 0.5 \\
\hline Brazil & 2 & 1.0 \\
\hline Bulgaria & 1 & 0.5 \\
\hline China & 147 & 72.1 \\
\hline Colombia & 4 & 2.0 \\
\hline Costa Rica & 1 & 0.5 \\
\hline Dominican Rep. & 1 & 0.5 \\
\hline Egypt & 2 & 1.0 \\
\hline Ecuador & 2 & 1.0 \\
\hline France & 1 & 0.5 \\
\hline Guyana & 1 & 0.5 \\
\hline Indonesia & 2 & 1.0 \\
\hline Italy & 1 & 0.5 \\
\hline Japan & 2 & 1.0 \\
\hline Korea & 8 & 3.9 \\
\hline Mexico & 1 & 0.5 \\
\hline Netherlands & 1 & 0.5 \\
\hline Peru & 1 & 0.5 \\
\hline Qatar & 3 & 1.5 \\
\hline Saint Lucia & 1 & 0.5 \\
\hline Singapore & 1 & 0.5 \\
\hline Switzerland & 1 & 0.5 \\
\hline Taiwan & 2 & 1.0 \\
\hline Thailand & 6 & 2.9 \\
\hline Trinidad & 2 & 1.0 \\
\hline UAE & 3 & 1.5 \\
\hline Venezuela & 1 & 0.5 \\
\hline Total & 203 & 100.0 \\
\hline
\end{tabular}




\section{Copyrights}

Copyright for this article is retained by the author(s), with first publication rights granted to the journal.

This is an open-access article distributed under the terms and conditions of the Creative Commons Attribution license (http://creativecommons.org/licenses/by/3.0/). 